\title{
New Lipophilic Fluorescent Dyes for Labeling Extracellular Vesicles: Characterization and Monitoring of Cellular Uptake
}

\author{
Takashi Shimomura, ${ }^{\dagger}{ }^{*}$ Ryo Seino, ${ }^{\dagger}$ Kaori Umezaki, ${ }^{\ddagger}$ Asako Shimoda, ${ }^{\ddagger}$ Takatoshi \\ Ezoe, ${ }^{\dagger}$ Munetaka Ishiyama† and Kazunari Akiyoshi ${ }^{\ddagger}$ \\ tDojindo Laboratories, 2025-5 Tabaru, Mashiki-machi, Kumamoto, 861-2202, Japan \\ ‡Department of Polymer Chemistry, Graduate School of Engineering, Kyoto University, \\ Katsura, Kyoto 615-8510, Japan
}

\section{General Materials}

Chemical reagents for synthesis: All chemicals were purchased from Fuji Film WakoPure Chemical Corporation (Osaka, Japan), Tokyo Chemical Industries (Tokyo, Japan), or SigmaAldrich (St. Louis, MO, USA), and used as purchased unless stated otherwise.

Reagents for cell culture and confocal microscopy: HeLa cells were obtained from RIKEN cell bank (Ibaraki, Japan). HEK293S $\mathrm{GnTI}^{-}$cells were obtained from ATCC (Manassas, VA, USA). Minimum essential medium (MEM), Trypsin-EDTA (0.25\%), fetal bovine serum (FBS) with Pen/Strep, HBSS, 293SFM II, and CTS ${ }^{\mathrm{TM}}$ GlutaMAX ${ }^{\mathrm{TM}}$-I were purchased from Thermo Fisher Scientific (Waltham, MA, USA). Micro BCA assay kit was purchased from Pierce (Rockford, IL, USA). Filtration tubes was purchased from Pall (Port Washington, NY, USA). PKH26 and PKH67 were purchased from Sigma-Aldrich.

\section{General Methods}

Nuclear magnetic resonance (NMR) spectroscopy: ${ }^{1} \mathrm{H}$ NMR spectra were recorded on a Bruker AVANCE III HD $400 \mathrm{MHz}$ spectrometer. NMR data were analyzed by TOPSPIN software. ${ }^{1} \mathrm{H}$ NMR chemical shifts are reported in units of ppm relative to tetramethylsilane. Electrospray ionization mass spectra were measured on an SQD2 instrument (Waters, Milford, MA, USA).

Fluorescence spectroscopic studies were performed on a FP-6300 fluorescence spectrophotometer (JASCO, Tokyo, Japan) or an Infinite m200 pro plate reader (Tecan Group Ltd., Männedorf, Switzerland). Nanoparticle tracking analysis (NTA) was performed on a NanoSight LM10 device (Malvern Instruments Ltd, Malvern, PA, USA). Zeta potential measurements were performed using a Zetasizer Nano ZS instrument (Malvern Instruments, UK). 


\section{Synthesis}

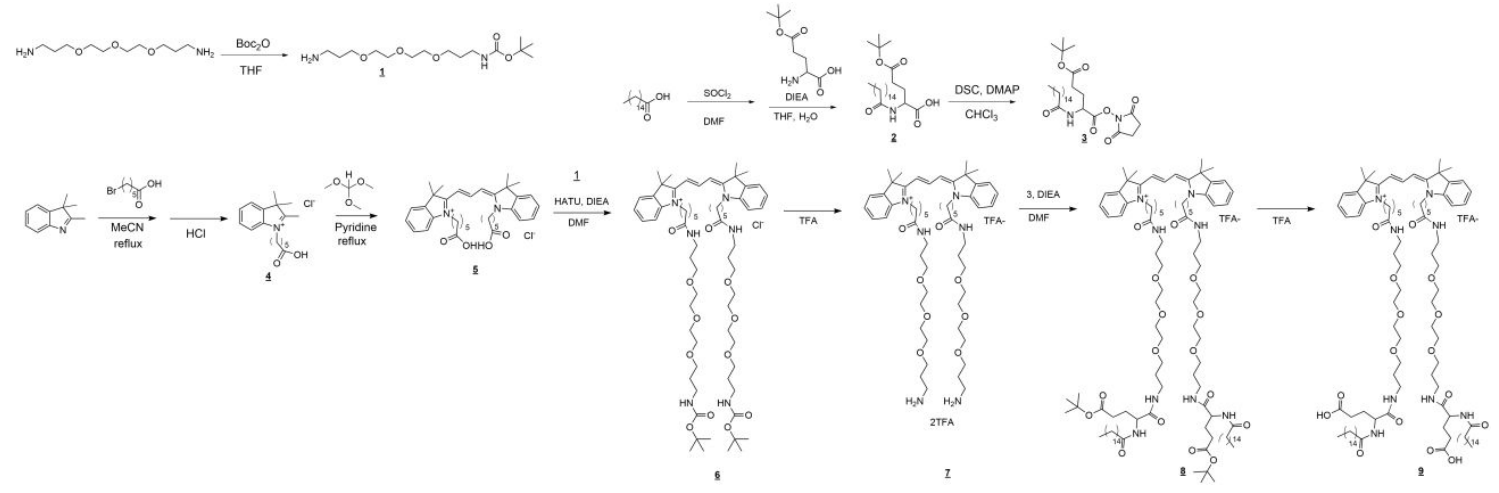

\section{Compound 1}

4,7,10-Trioxa-1,13-tridecanediamine (14 g, 62.6mmol) was dissolved in tetrahydrofuran (THF, 10 $\mathrm{mL})$. The solution was cooled to $0{ }^{\circ} \mathrm{C}$ in an ice bath, and di-tert-butyl dicarbonate $(2.7 \mathrm{~g}$, $12.5 \mathrm{mmol})$ diluted in THF $(10 \mathrm{~mL})$ was added dropwise. The mixture was stirred overnight at room temperature, and then the solvent was evaporated in vacuo. The crude was dissolved in chloroform $\left(\mathrm{CHCl}_{3}\right)$ and washed with brine. The organic layer was dried $\left(\mathrm{Na}_{2} \mathrm{SO}_{4}\right)$, filtered, and the solvent was removed to give the crude compound 1, which was then purified by silica-gel chromatography from $\mathrm{CHCl}_{3}$ and methanol (MeOH) to give pure compound 1 as a yellowish oil (4.7 g, yield= 23\%). ${ }^{1} \mathrm{H}$ NMR (400 MHz, MeOD): $\delta=3.51-3.65(\mathrm{~m}, 14 \mathrm{H}), 3.14(\mathrm{t}, J=6.8 \mathrm{~Hz}, 2 \mathrm{H})$, $2.78(\mathrm{t}, \mathrm{J}=6.8 \mathrm{~Hz}, 2 \mathrm{H}), 1.80-1.71(\mathrm{~m}, 4 \mathrm{H}), 1.45(\mathrm{~s}, 9 \mathrm{H})$.

\section{Compound 2}

To synthesize palmitoyl chloride, palmitic acid $(1.5 \mathrm{~g}, 5.86 \mathrm{mmol})$, thionyl chloride $(42 \mathrm{~mL}, 58.6$ $\mathrm{mmol}$ ), and 1 drop of dimethylformamide (DMF) were mixed in a flask. The mixture was then allowed to react for 1 hour at $60{ }^{\circ} \mathrm{C}$. Then the solution was concentrated, and anhydrous toluene was added and concentrated to remove excess thionyl chloride.

L-Glutamic acid-y-tert-butyl ester $(1.19 \mathrm{~g}, 5.86 \mathrm{mmol})$ and diisopropylethylamine $(2.045 \mathrm{~mL}, 11.72$ $\mathrm{mmol})$ were dissolved in water $(100 \mathrm{~mL})$ and THF $(100 \mathrm{~mL})$. The solution was stirred for $5 \mathrm{~min}$, then palmitoyl chloride (0.5 M in THF, $11 \mathrm{~mL}$ ) was added dropwise. The solution was stirred for $1 \mathrm{~h}$ at room temperature. The reaction mixture was diluted with $\mathrm{CHCl}_{3}$ and acidified with $5 \%$ citric acid aqueous solution. The organic layer was washed with brine $(100 \mathrm{~mL})$. The organic layer was dried 
$\left(\mathrm{Na}_{2} \mathrm{SO}_{4}\right)$, filtered, and the solvent was removed to give the crude compound 2, which was then purified by silica-gel chromatography from $\mathrm{CHCl}_{3}$ and $\mathrm{MeOH}$ to give pure compound 2 as a white solid (2 g, yield = 80\%). ${ }^{1} \mathrm{H}$ NMR (400 MHz, MeOD): $\delta=4.50-4.40(\mathrm{~m}, 1 \mathrm{H}), 2.35(\mathrm{t}, J=7.2 \mathrm{~Hz}, \mathrm{t})$, $2.26(\mathrm{t}, J=7.2 \mathrm{~Hz}, \mathrm{t}), 2.10-2.20(\mathrm{~m}, 1 \mathrm{H}), 1.95-1.85(\mathrm{~m}, 1 \mathrm{H}), 1.70-1.60(\mathrm{~m}, 2 \mathrm{H}), 1.47(\mathrm{~s}, 9 \mathrm{H}), 1.40-$ $1.31(\mathrm{~m}, 24 \mathrm{H}), 0.91(\mathrm{t}, J=7.2 \mathrm{~Hz}, 3 \mathrm{H})$.

\section{Compound 3}

Compound 2 (300 mg, $0.7 \mathrm{mmol})$ was dissolved in $\mathrm{CHCl}_{3}(100 \mathrm{~mL})$ and cooled to $0^{\circ} \mathrm{C}$ in an ice bath. The solution was stirred for $5 \mathrm{~min}$, then di-succinimidyl carbonate $\left(0.5 \mathrm{M}\right.$ in $\left.\mathrm{CHCl}_{3}, 1.4 \mathrm{~mL}\right)$ was added dropwise. The solution was stirred for 3 hours at $0{ }^{\circ} \mathrm{C}$, following the addition of a catalytic amount of $\mathrm{N}, \mathrm{N}$-dimethylaminopyridine. The solvent was removed to give the crude compound 3, which was then purified by silica-gel chromatography from hexane and ethyl acetate to give pure compound $\mathbf{3}$ as a white solid, which was used for the next step without further purification.

\section{Compound 4}

2,3,3-Trimethylindolenine $(5 \mathrm{~g}, 31.4 \mathrm{mmol})$ and bromohexanoic acid $(6.1 \mathrm{~g}, 31.4 \mathrm{mmol})$ were dissolved with acetonitrile $(100 \mathrm{~mL})$. The solution was refluxed with stirring overnight. Then, the solution was cooled to room temperature and the solvent was removed. The crude was washed with cold diethyl ether several times and was dried under reduced pressure to give compound 4 as a brownish-red solid, which was used for the next step without further purification.

\section{Compound 5}

Compound 4 (1.7g, 4.79mmol) was dissolved with dry pyridine $(10 \mathrm{~mL})$. Trimethyl orthoformate $(470 \mu \mathrm{L}, 28.2 \mathrm{mmol})$ was added and the solution was refluxed with stirring overnight. The solution was cooled to room temperature. Then the solvent was removed. The red solid was dissolved with $\mathrm{CHCl}_{3}$ and washed successively with $1 \mathrm{M} \mathrm{HCl}_{\mathrm{aq}}$ and brine. The organic layer was dried $\left(\mathrm{Na}_{2} \mathrm{SO}_{4}\right)$, filtered, and the solvent was removed to give the crude compound $\mathbf{5}$, which was then purified by silica-gel chromatography from $\mathrm{CHCl}_{3}$ and $\mathrm{MeOH}$ to give pure compound 5 as a red solid $(0.7 \mathrm{~g}$, yield $=31 \%) .{ }^{1} \mathrm{H}$ NMR $\left(400 \mathrm{MHz}, \mathrm{CDCl}_{3}\right): \delta=8.41(\mathrm{t}, \mathrm{J}=13.6 \mathrm{~Hz}, 1 \mathrm{H})$, 7.46-7.42 (m, 4H), $7.13(\mathrm{~d}, J=7.6 \mathrm{~Hz}, 2 \mathrm{H}), 6.98(\mathrm{~d}, J=13.6 \mathrm{~Hz}, 2 \mathrm{H}), 4.21(\mathrm{t}, J=7.6 \mathrm{~Hz}, 4 \mathrm{H})$, 
$2.52(\mathrm{t}, J=6.8 \mathrm{~Hz}, 4 \mathrm{H}), 1.95-1.85(\mathrm{~m}, 4 \mathrm{H}), 1.85-1.75(\mathrm{~m}, 4 \mathrm{H}), 1.70(\mathrm{~m}, 4 \mathrm{H}), 1.70-1.60(\mathrm{~m}$, $4 \mathrm{H})$.

\section{Compound 6}

Compound $5(21.5 \mathrm{mg}, 36.3 \mu \mathrm{mol})$ and HATU $(30.4 \mathrm{mg}, 80 \mu \mathrm{mol})$ were dissolved with DMF. The solution was stirred for $\mathbf{2 0}$ min at room temperature. Then DMF solution containing compound 1 (50mg, $70 \mu \mathrm{mol})$ and diisopropylethylamine $(16 \mu \mathrm{L}, 90.75 \mu \mathrm{mol})$ was added dropwise. The solution was stirred overnight at room temperature. The solvent was removed and dissolved with $\mathrm{CHCl}_{3}$. The solution was washed successively with $5 \%$ citric acid aqueous solution and brine. The organic layer was dried $\left(\mathrm{Na}_{2} \mathrm{SO}_{4}\right)$, filtered, and the solvent was removed to give the crude compound 6 , which was then purified by silica-gel chromatography from $\mathrm{CHCl}_{3}$ and $\mathrm{MeOH}$ to give pure compound 6 as a red solid $(35 \mathrm{mg}$, yield $=80.5 \%) .{ }^{1} \mathrm{H} \mathrm{NMR}(400 \mathrm{MHz}$, $\left.\mathrm{CDCl}_{3}\right): \delta=8.60(\mathrm{t}, J=12.0 \mathrm{~Hz}, 1 \mathrm{H}), 7.65(\mathrm{~d}, J=7.6 \mathrm{~Hz}, 2 \mathrm{H}), 7.58(\mathrm{~d}, J=7.6 \mathrm{~Hz}, 2 \mathrm{H}), 7.55-7.45$ $(\mathrm{m}, 4 \mathrm{H}), 6.06(\mathrm{~d}, J=13.2 \mathrm{~Hz}, 2 \mathrm{H}), 4.23(\mathrm{t}, J=7.2 \mathrm{~Hz}, 4 \mathrm{H}), 3.75-3.55(\mathrm{~m}, 16 \mathrm{H}), 3.55-3.45(\mathrm{~m}, 8 \mathrm{H})$, 3.30-3.20 (m, 4H), 3.20-3.10 (m, 4H), $2.21(\mathrm{t}, \mathrm{J}=7.2 \mathrm{~Hz}, 4 \mathrm{H}), 2.00-1.90(\mathrm{~m}, 4 \mathrm{H}), 1.80-1.65(\mathrm{~m}$, $12 \mathrm{H}), 1.60-1.43(\mathrm{~m}, 22 \mathrm{H})$.

\section{Compound 7, 8}

Compound 6 (200 mg, $168 \mu \mathrm{mol})$ was dissolved with $\mathrm{CHCl}_{3}(10 \mathrm{~mL})$. Then, trifluoroacetic acid (TFA, $10 \mathrm{~mL}$ ) was added and stirred for 1 hour at $40^{\circ} \mathrm{C}$. The solvent was removed to give compound 7 , which was used for the next step without further purification. The solid was dissolved with DMF and neutralized with diisopropylethylamine. A solution of compound $3(0.5 \mathrm{M}$ in DMF, $800 \mu \mathrm{L})$ was added dropwise. The solution was stirred overnight at room temperature. The solvent was removed and dissolved with $\mathrm{CHCl}_{3}$. The solution was washed successively with $5 \%$ citric acid aqueous solution and brine. The organic layer was dried $\left(\mathrm{Na}_{2} \mathrm{SO}_{4}\right)$, filtered, and the solvent was removed to give the crude compound $\mathbf{8}$, which was then purified by silica-gel chromatography from $\mathrm{CHCl}_{3}$ and $\mathrm{MeOH}$ to give compound 8 as a red solid (100 mg).

\section{Compound 9}

Compound 8 (100 mg, $52 \mu \mathrm{mol})$ was dissolved with $\mathrm{CHCl}_{3}(10 \mathrm{~mL})$. Then, TFA (10 mL) was added and stirred for 1 hour at $40^{\circ} \mathrm{C}$. The solvent was removed to give crude compound 9 . The solid was dissolved with acetonitrile and water, which was then purified by reverse-phase chromatography from acetonitrile and water containing $0.1 \%$ TFA to give pure compound 9 as a 
red solid (20 mg, yield = 21\%). ${ }^{1} \mathrm{H}$ NMR $(400 \mathrm{MHz}, \mathrm{MeOD}): \delta=8.61(\mathrm{t}, J=13.2 \mathrm{~Hz}, 1 \mathrm{H}), 7.66(\mathrm{~d}, J$ $=7.6 \mathrm{~Hz}, 2 \mathrm{H}), 7.60(\mathrm{~d}, J=7.6 \mathrm{~Hz}, 2 \mathrm{H}), 7.52-7.43(\mathrm{~m}, 4 \mathrm{H}), 6.06(\mathrm{~d}, J=13.2 \mathrm{~Hz}, 2 \mathrm{H}), 4.35-4.31(\mathrm{~m}$, $2 \mathrm{H}), 4.24(\mathrm{t}, J=7.2 \mathrm{~Hz}, 4 \mathrm{H}), 3.64-3.57(\mathrm{~m}, 16 \mathrm{H}), 3.51(\mathrm{q}, J=6.0$ and $12.4 \mathrm{~Hz}, 8 \mathrm{H}), 3.29-3.22(\mathrm{~m}$, 8H), 2.38 (t, $J=7.4 \mathrm{~Hz}, 4 \mathrm{H}), 2.22(\mathrm{q}, J=8.0$ and $15.6 \mathrm{~Hz}, 8 \mathrm{H}), 2.12-2.03(\mathrm{~m}, 2 \mathrm{H}), 1.95-1.80(\mathrm{~m}$, $6 \mathrm{H}), 1.80-1.70(\mathrm{~m}, 12 \mathrm{H}), 1.65-1.55(\mathrm{~m}, 4 \mathrm{H}), 1.55-1.45(\mathrm{~m}, 4 \mathrm{H}), 1.40-1.25(\mathrm{~m}, 48 \mathrm{H}), 0.91(\mathrm{t}, J=7.2$ $\mathrm{Hz}, 6 \mathrm{H}) . \mathrm{MS}-\mathrm{ESI}(\mathrm{m} / \mathrm{z})$ : [M] ${ }^{+}$calculated for $1644.11\left(\mathrm{C}_{91} \mathrm{H}_{151} \mathrm{~N}_{8} \mathrm{O}_{18}{ }^{+}\right)$, found 1644.17.

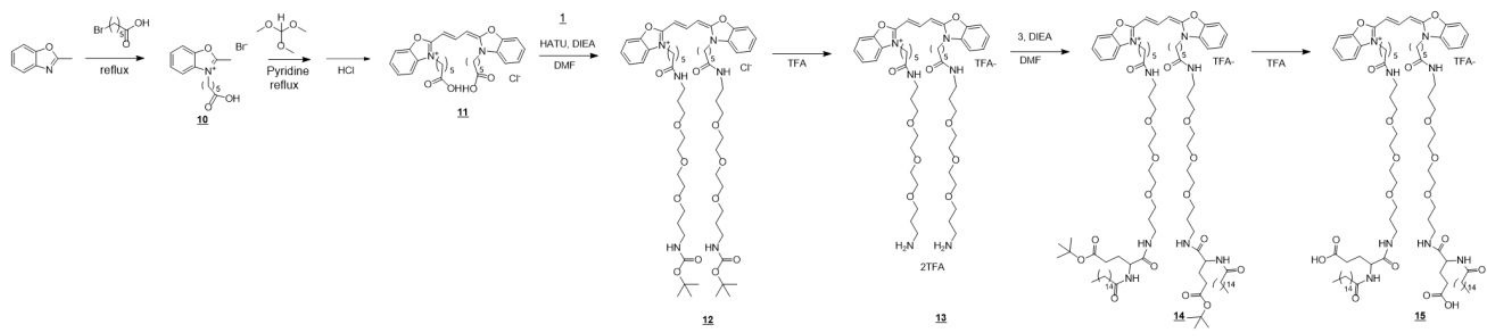

\section{Compound 10}

2-Methylbenzoxazole (40 g, $300 \mathrm{mmol}$ ), bromohexanoic acid (50 g, $250 \mathrm{mmol}$ ), potassium iodide $(41 \mathrm{~g}, 250 \mathrm{mmol})$, and acetonitrile $(50 \mathrm{~mL})$ were mixed. The solution was stirred and then the solution was refluxed with stirring overnight. Then, the solution was cooled to room temperature and then filtered to give crude compound 10. The filtrate was washed with acetonitrile and cold diethyl ether several times. The solid was dried under reduced pressure to give compound 10 as a brownish-white solid $(21.9 \mathrm{~g}$, yield $=25 \%) .{ }^{1} \mathrm{H}$ NMR $(400 \mathrm{MHz}, \mathrm{MeOD}): \delta=8.10(\mathrm{~d}, J=7.2 \mathrm{~Hz}$, 1H), $8.03(\mathrm{~d}, J=6.0 \mathrm{~Hz}, 1 \mathrm{H}), 7.85-7.75(\mathrm{~m}, 2 \mathrm{H}), 4.64(\mathrm{t}, J=7.6 \mathrm{~Hz}, 2 \mathrm{H}), 3.17(\mathrm{~s}, 3 \mathrm{H}), 2.37(\mathrm{t}, J=$ $7.2 \mathrm{~Hz}, 2 \mathrm{H}), 2.10-2.00(\mathrm{~m}, 2 \mathrm{H}), 1.80-1.70(\mathrm{~m}, 2 \mathrm{H}), 1.65-1.55(\mathrm{~m}, 2 \mathrm{H})$.

\section{Compound 11}

Compound 10 (12 g, $37 \mathrm{mmol})$ was dissolved with pyridine $(10 \mathrm{~mL})$. Trimethyl orthoformate $(7.8$ $\mathrm{mL}, 74 \mathrm{mmol}$ ) was added and the solution was refluxed for 2 hours. The solution was cooled to room temperature and then the solvent was removed. The yellow solid was dissolved with $\mathrm{CHCl}_{3}$ and washed successively with $1 \mathrm{M} \mathrm{HCl}_{\mathrm{aq}}$ and brine. The organic layer was dried $\left(\mathrm{Na}_{2} \mathrm{SO}_{4}\right)$, filtered, and the solvent was removed to give the crude compound 11, which was then purified by silica-gel chromatography from $\mathrm{CHCl}_{3}$ and $\mathrm{MeOH}$ to give pure compound 11 as a yellow solid (550 mg, yield $=5.5 \%$ ). ${ }^{1} \mathrm{H}$ NMR (400 MHz, MeOD): $\delta=8.60$ (t, $\left.J=13.2 \mathrm{~Hz}, 1 \mathrm{H}\right)$, $7.62(\mathrm{dd}, J=8.0$ and $21.6 \mathrm{~Hz}, 4 \mathrm{H}), 7.50-7.41(\mathrm{~m}, 4 \mathrm{H}), 6.06(\mathrm{~d}, \mathrm{~J}=6.6 \mathrm{~Hz}, 2 \mathrm{H}), 4.23(\mathrm{t}, J=7.2 \mathrm{~Hz}$, 4H), 2.28 (t, $J=7.2 \mathrm{~Hz}, 4 \mathrm{H}), 2.00-1.90(\mathrm{~m}, 4 \mathrm{H}), 1.75-1.65(\mathrm{~m}, 4 \mathrm{H}), 1.60-1.45(\mathrm{~m}, 4 \mathrm{H})$. 


\section{Compound 12}

Compound 11 (550 mg, $1.09 \mathrm{mmol}$ ) and HATU (2.47 mg, $6.54 \mathrm{mmol}$ ) were dissolved with DMF $(50 \mathrm{~mL})$. The solution was stirred for $20 \mathrm{~min}$ at room temperature. Then a DMF solution containing compound $1(2.1 \mathrm{~g}, 6.54 \mathrm{mmol})$ was added dropwise. The solution was stirred overnight at room temperature. The solvent was removed and dissolved with $\mathrm{CHCl}_{3}$. The solution was washed successively with $1 \mathrm{M} \mathrm{HCl}_{\mathrm{aq}}$ and brine. The organic layer was dried $\left(\mathrm{Na}_{2} \mathrm{SO}_{4}\right)$, filtered, and the solvent was removed to give the crude compound 12 , which was then purified by silica-gel chromatography from $\mathrm{CHCl}_{3}$ and $\mathrm{MeOH}$ to give pure compound 12 as a yellow solid (980 mg, yield $=81 \%) .{ }^{1} \mathrm{H}$ NMR $(400 \mathrm{MHz}, \mathrm{MeOD}): \delta=8.60(\mathrm{t}, J=13.2 \mathrm{~Hz}, 1 \mathrm{H})$, $7.62(\mathrm{dd}, J=8.0$ and $21.6 \mathrm{~Hz}, 4 \mathrm{H}), 7.52-7.44(\mathrm{~m}, 4 \mathrm{H}), 6.06(\mathrm{~d}, J=13.2 \mathrm{~Hz}, 2 \mathrm{H}), 4.23(\mathrm{t}, J=7.2$ $\mathrm{Hz}, 4 \mathrm{H}), 3.70-3.50(\mathrm{~m}, 16 \mathrm{H}), 3.40-3.30(\mathrm{~m}, 8 \mathrm{H}), 3.30-3.10(\mathrm{~m}, 8 \mathrm{H}), 2.21(\mathrm{t}, J=7.2 \mathrm{~Hz}, 4 \mathrm{H}), 2.00-$ $1.90(\mathrm{~m}, 4 \mathrm{H}), 1.80-1.65(\mathrm{~m}, 12 \mathrm{H}), 1.60-1.43(\mathrm{~m}, 22 \mathrm{H})$.

\section{Compound 13, 14}

Compound 12 (980 mg, $0.88 \mathrm{mmol})$ was dissolved with $\mathrm{CHCl}_{3}(30 \mathrm{~mL})$. Then, TFA(3 mL) was added and stirred for 2 hours at $45^{\circ} \mathrm{C}$. The solvent was removed to give compound 13 , which was used for the next step without further purification. The solid was dissolved with DMF and neutralized with diisopropylethylamine. A DMF solution containing compound $3(0.5 \mathrm{M}, 6 \mathrm{~mL})$ was added dropwise. The solution was stirred overnight at room temperature. The solvent was removed and dissolved with $\mathrm{CHCl}_{3}$. The solution was washed successively with $1 \mathrm{MHCl}_{\mathrm{aq}}$ and brine. The organic layer was dried $\left(\mathrm{Na}_{2} \mathrm{SO}_{4}\right)$, filtered. and the solvent was removed to give the crude compound 14, which was then purified by silica-gel chromatography from $\mathrm{CHCl}_{3}$ and $\mathrm{MeOH}$ to give compound 14 as a yellow solid $(880 \mathrm{mg})$.

\section{Compound 15}

Compound $14(880 \mathrm{mg})$ was dissolved with $\mathrm{CHCl}_{3}(30 \mathrm{~mL})$. Then, TFA $(10 \mathrm{~mL})$ was added and stirred for 1.5 hours at $40^{\circ} \mathrm{C}$. The solvent was removed to give crude compound 15 . The solid was dissolved with acetonitrile and water, which was then purified by reverse-phase chromatography from acetonitrile and water containing $0.1 \%$ TFA to give pure compound 15 as a yellow solid (90 mg, yield $=10 \%) .{ }^{1} \mathrm{H}$ NMR (400 MHz, MeOD): $\delta=8.57$ (t, $J=13.6 \mathrm{~Hz}$, 1H), $7.57(\mathrm{~d}, J=7.6 \mathrm{~Hz}, 2 \mathrm{H}), 7.48(\mathrm{t}, J=7.6 \mathrm{~Hz}, 2 \mathrm{H}), 7.40-7.32(\mathrm{~m}, 4 \mathrm{H}), 6.51(\mathrm{~d}, J=13.2 \mathrm{~Hz}$, 2H), 4.35-4.31 (m, 2H), $4.18(\mathrm{t}, J=7.2 \mathrm{~Hz}, 4 \mathrm{H}), 3.64-3.57(\mathrm{~m}, 16 \mathrm{H}), 3.51(\mathrm{q}, \mathrm{J}=6.0$ and $12.4 \mathrm{~Hz}$, 
8H), 3.29-3.22 (m, 8H), $2.38(\mathrm{t}, J=7.4 \mathrm{~Hz}, 4 \mathrm{H}), 2.22(\mathrm{q}, J=8.0$ and $15.6 \mathrm{~Hz}, 8 \mathrm{H}), 2.12-2.03(\mathrm{~m}$, $2 \mathrm{H}), 1.95-1.80(\mathrm{~m}, 6 \mathrm{H}), 1.80-1.70(\mathrm{~m}, 24 \mathrm{H}), 1.65-1.55(\mathrm{~m}, 4 \mathrm{H}), 1.55-1.45(\mathrm{~m}, 4 \mathrm{H}), 1.40-1.25(\mathrm{~m}$, $48 \mathrm{H}), 0.91(\mathrm{t}, J=7.2 \mathrm{~Hz}, 6 \mathrm{H})$. MS-ESI (m/z): [M] ${ }^{+}$calculated for $1696.22\left(\mathrm{C}_{97} \mathrm{H}_{163} \mathrm{~N}_{8} \mathrm{O}_{16}{ }^{+}\right)$, found 1696.63.

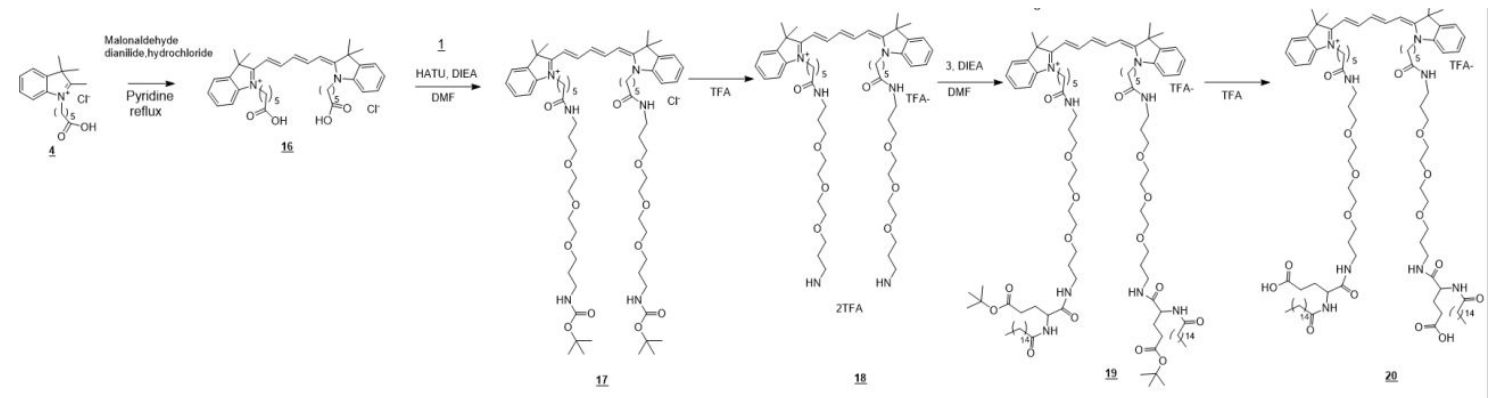

\section{Compound 16}

Compound 4 (2.5 g, $7.06 \mathrm{mmol})$ was dissolved with pyridine $(30 \mathrm{~mL})$. Malonaldehyde dianilide hydrochloride $(3.65 \mathrm{~g}, 14.1 \mathrm{mmol}$ ) was added and the solution was refluxed overnight. The solution was cooled to room temperature. Then the solvent was removed. The blue solid was dissolved with $\mathrm{CHCl}_{3}$ and washed successively with $1 \mathrm{M} \mathrm{HCl}_{\mathrm{aq}}$ and brine. The organic layer was dried $\left(\mathrm{Na}_{2} \mathrm{SO}_{4}\right)$, filtered, and the solvent was removed to give a blue solid, which was then purified by silica-gel chromatography from $\mathrm{CHCl}_{3}$ and $\mathrm{MeOH}$ to give compound 16 as a blue solid $(1 \mathrm{~g})$.

\section{Compound 17-20}

These compounds were synthesized in the same manner as compounds $6-9$, respectively. Compound 20 (16 mg). ${ }^{1} \mathrm{H}$ NMR (400 MHz, MeOD): $\delta=8.27$ (t, $\left.J=13.0 \mathrm{~Hz}, 2 \mathrm{H}\right), 7.52$ (d, $J=$ $7.6 \mathrm{~Hz}, 2 \mathrm{H}), 7.44$ (t, J = 7.4 Hz, 2H), 7.33-7.27 (m, 4H), 6.63 (t, $J=11.2 \mathrm{~Hz}, 1 \mathrm{H}), 6.31$ (d, J = 13.6 $\mathrm{Hz}, 2 \mathrm{H}), 4.35-4.31(\mathrm{~m}, 2 \mathrm{H}), 4.14(\mathrm{t}, J=7.2 \mathrm{~Hz}, 4 \mathrm{H}), 3.65-3.52(\mathrm{~m}, 16 \mathrm{H}), 3.51-3.4(\mathrm{~m}, 8 \mathrm{H}), 3.29-$ $3.20(\mathrm{~m}, 8 \mathrm{H}), 2.38(\mathrm{t}, J=7.4 \mathrm{~Hz}, 4 \mathrm{H}), 2.30-2.20(\mathrm{~m}, 8 \mathrm{H}), 2.10-2.00(\mathrm{~m}, 2 \mathrm{H}), 1.95-1.80(\mathrm{~m}, 6 \mathrm{H})$, 1.80-1.70 (m, 12H), 1.65-1.55 (m, 4H),1.55-1.45 (m, 4H), 1.40-1.25 (m, 48H), 0.91 (t, J = 7.2 Hz, 6H). MS-ESI (m/z): [M] calculated for $1723.24\left(\mathrm{C}_{99} \mathrm{H}_{165} \mathrm{~N}_{8} \mathrm{O}_{16}{ }^{+}\right)$, found 1723.50 . 


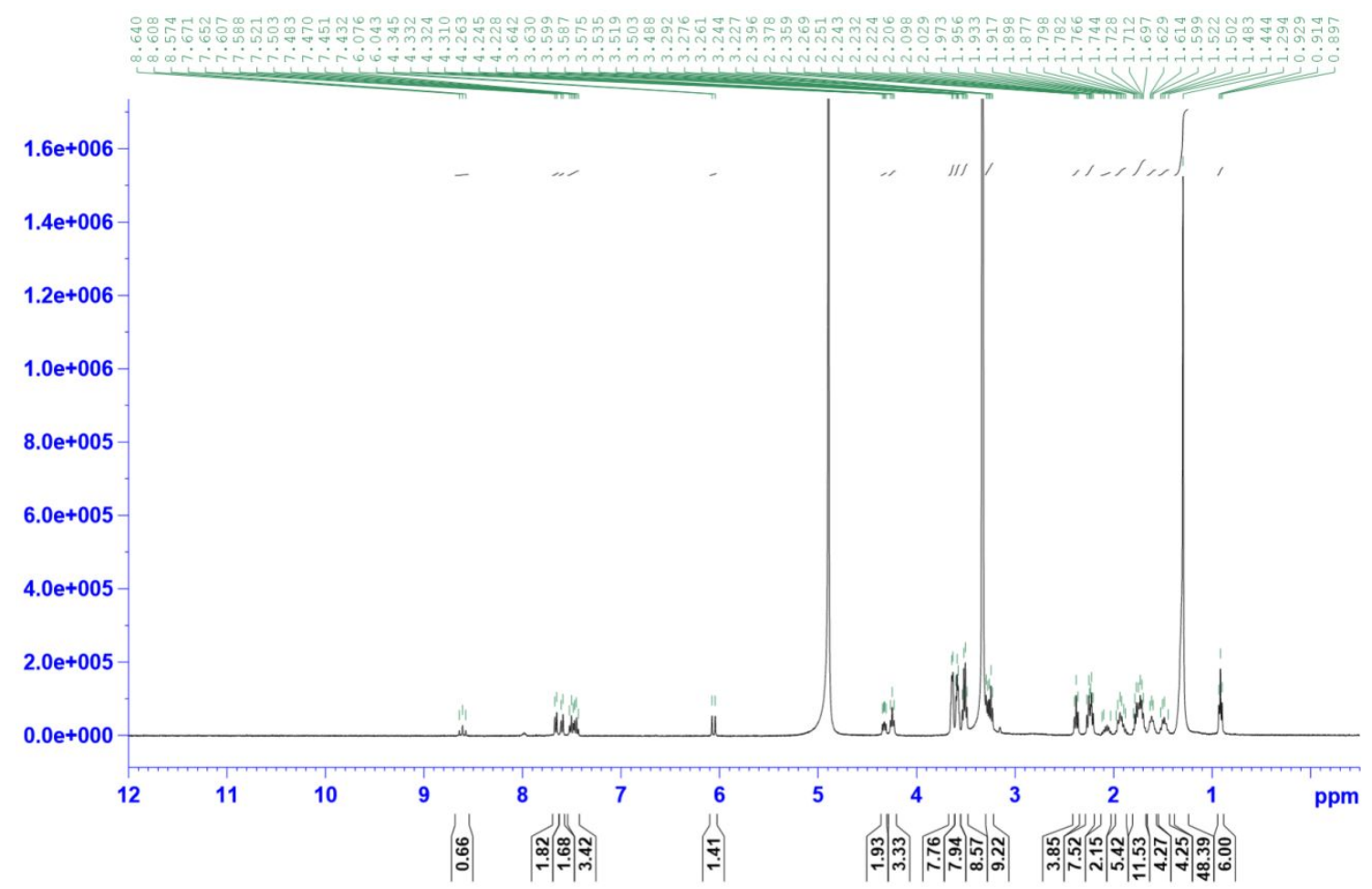

(a) Compound 9 (Mem dye-Green)

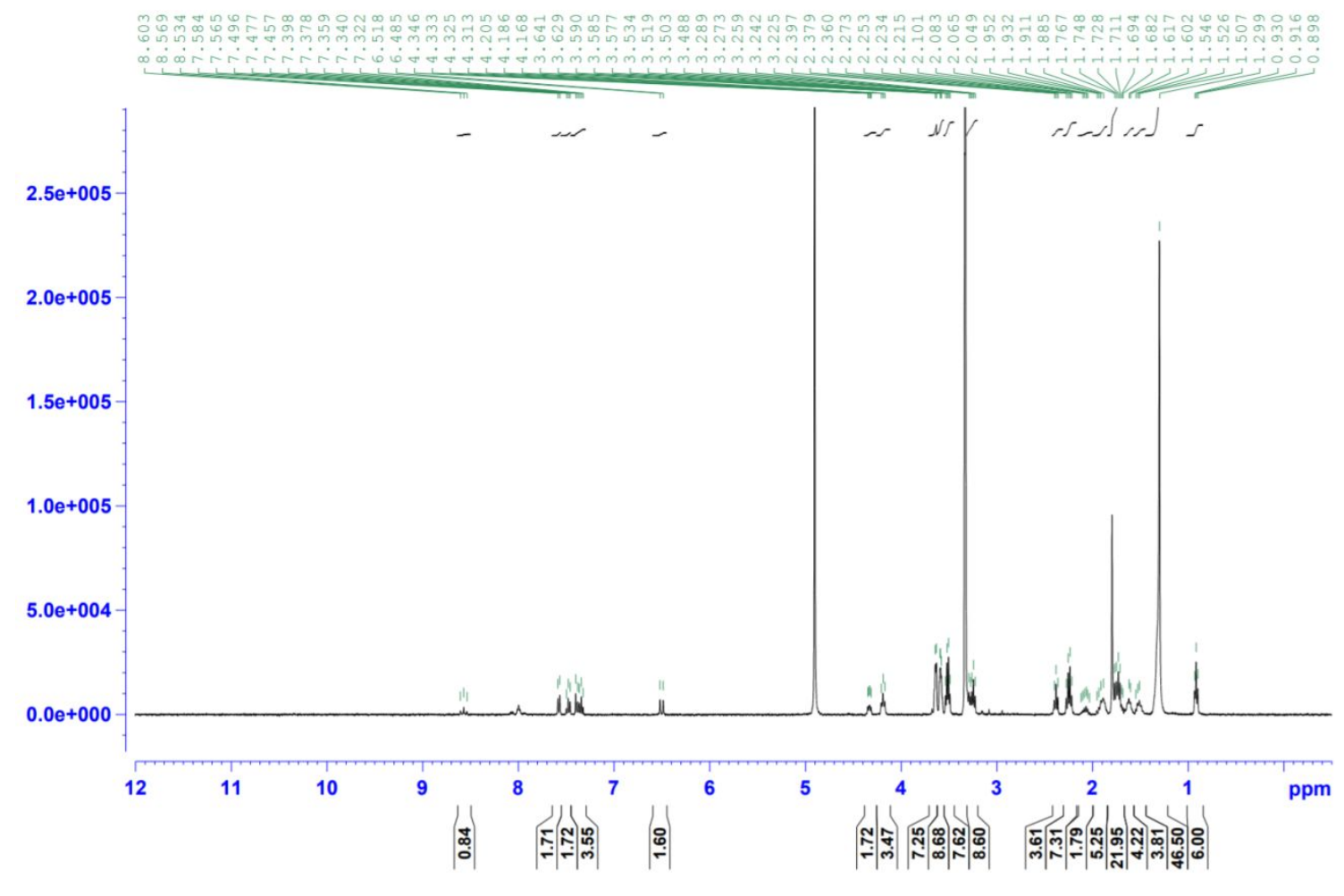

(b) Compound 15 (Mem dye-Red) 


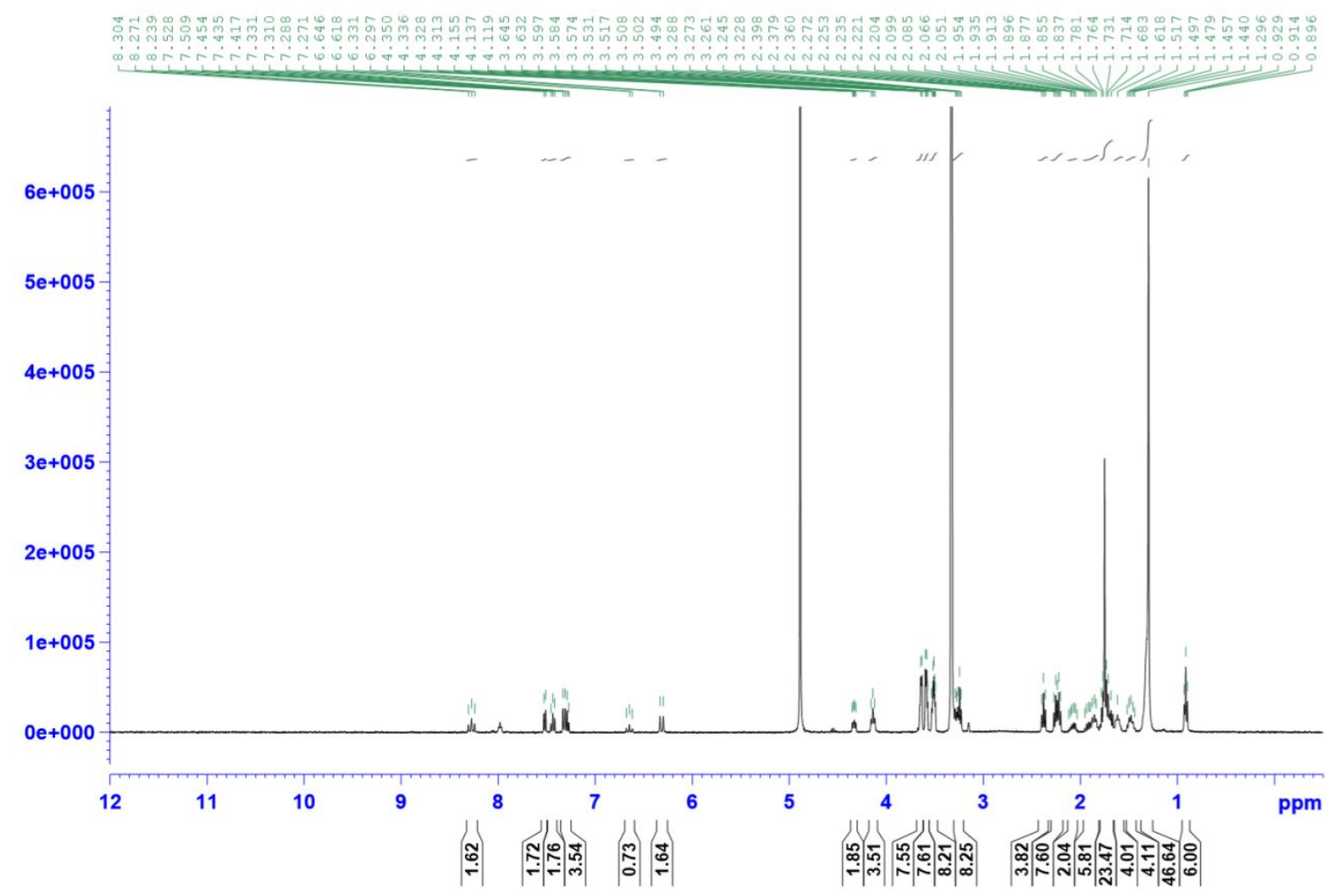

(c) Compound 20 (Mem dye-Deep Red)

Figure S1. ${ }^{1} \mathrm{H}$ NMR spectra (400 MHz) of Mem dyes. (a) Mem dye-Green, (b) Mem dye-Red, (c) Mem dye-Deep Red. 


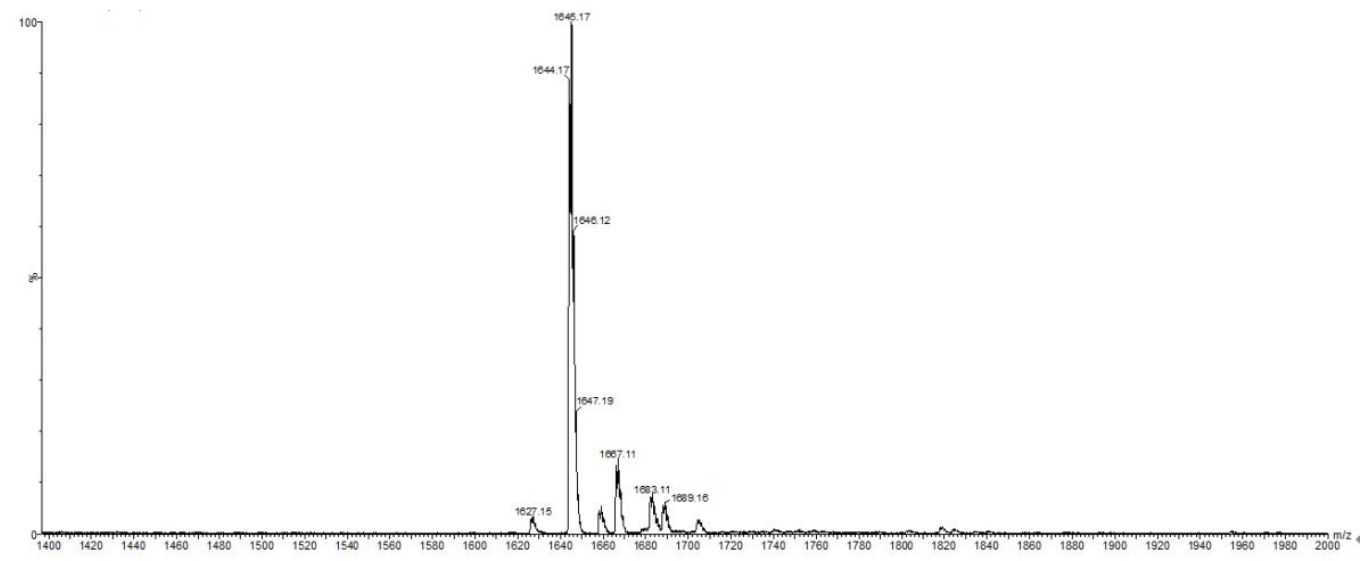

(a) Compound 9 (Mem dye-Green)

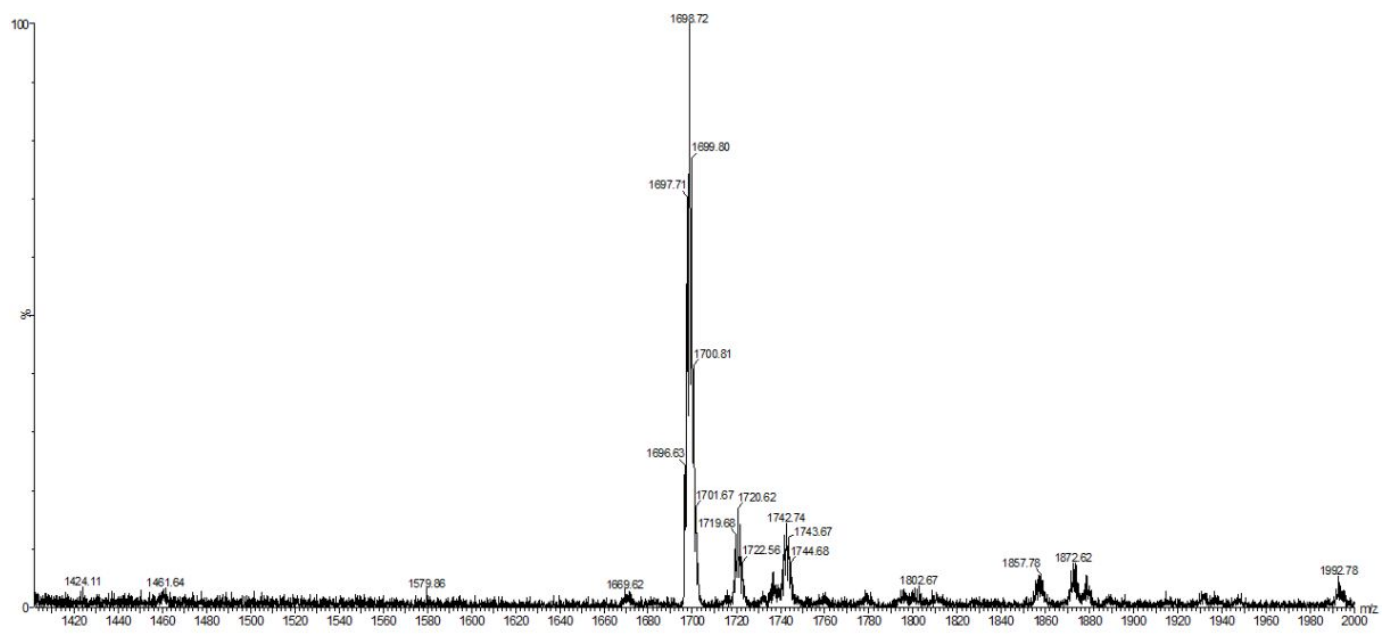

(b) Compound 15 (Mem dye-Red)

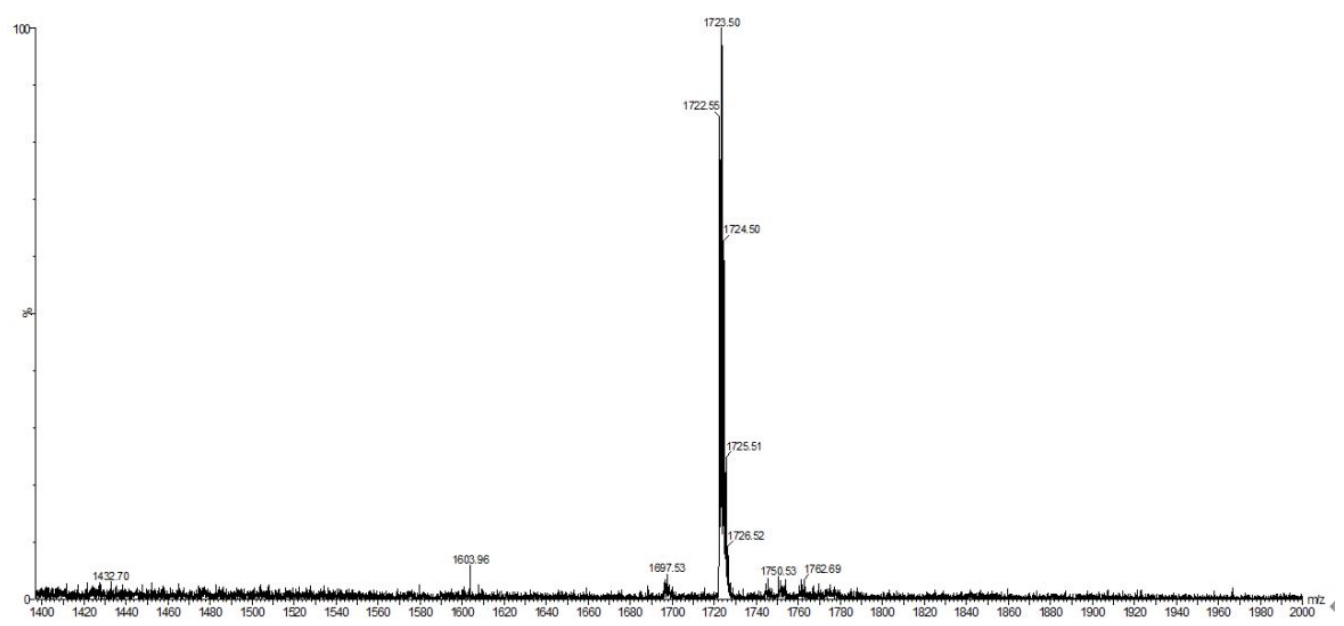

(c) Compound 20 (Mem dye-Deep Red)

Figure S2. ESI-MS spectra of Mem dyes. (a) Mem dye-Green, (b) Mem dye-Red, (c) Mem dye-Deep Red. 


\section{Experimental Procedures}

Photophysical properties

The Mem dyes were dissolved in dimethylsulfoxide to prepare $0.5 \mathrm{mM}$ solutions. Then, the Mem dyes/dimethylsulfoxide solution was diluted 100 times with dimethylsulfoxide. The fluorescence spectrum of each solution was measured.
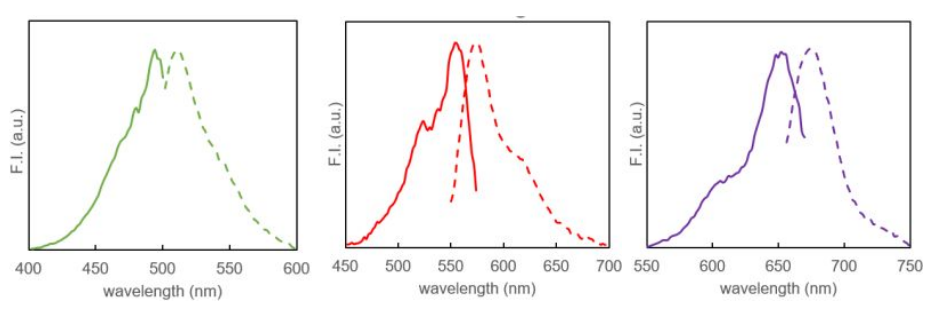

Figure S3. Fluorescence spectrum of Mem dyes $(5 \mu \mathrm{M})$. (Mem dye-Green: $\lambda_{\mathrm{ex}}=494 \mathrm{~nm}, \lambda_{\mathrm{em}}$ $=512 \mathrm{~nm}$, Mem dye-Red: $\lambda_{\mathrm{ex}}=554 \mathrm{~nm}, \lambda_{\mathrm{em}}=572 \mathrm{~nm}$, Mem dye-Deep Red: $\lambda_{\mathrm{ex}}=652 \mathrm{~nm}, \lambda_{\mathrm{em}}$ $=672 \mathrm{~nm})$.

\section{Cell culture}

HeLa cells were cultured with MEM supplemented with 10\% (v/v) FBS, 2 mM L-glutamine, $1 \%$ nonessential amino acids, $100 \mathrm{unit} / \mathrm{mL}$ penicillin, and $100 \mu \mathrm{g} / \mathrm{mL}$ streptomycin in a humidified $5 \% \mathrm{CO}_{2}$ incubator at $37^{\circ} \mathrm{C}$. HEK293S $\mathrm{GnTl}^{-}$cells were cultured under suspension conditions with $293 \mathrm{SFM}$ II containing CTS ${ }^{\mathrm{TM}}$ GlutaMAX $^{\mathrm{TM}}-\mathrm{I}$ at $37^{\circ} \mathrm{C}$ in an atmosphere with $5 \%$ $\mathrm{CO}_{2}$.

\section{Isolation of HEK293S-derived sEV}

For HEK293S-derived sEV isolation, $1.5 \times 10^{7}$ cells were cultured in fresh growth medium for $48 \mathrm{~h}$ before collecting the supernatant. The resulting conditioned media were centrifuged at $125 \times g$ for $10 \mathrm{~min}, 10,000 \times g$ for $20 \mathrm{~min}$, and then $100,000 \times g$ for $120 \mathrm{~min}$ at $4{ }^{\circ} \mathrm{C}$. Subsequently, the sEV pellets were washed with phosphate-buffered saline (PBS) by ultracentrifugation at $120,000 \times \mathrm{g}$ for $120 \mathrm{~min}$ at $4{ }^{\circ} \mathrm{C}$. sEV pellets were resuspended in PBS and stored at $-80{ }^{\circ} \mathrm{C}$ until use. The concentration of the proteins of the sEV was determined using a Micro BCA assay kit. 
Fluorescent cell membrane staining

Mem dyes staining solutions $(1 \mu \mathrm{M})$ were prepared with Hanks' Balanced Salt Solution (HBSS). HeLa cells were grown on microwell slides and incubated with Mem dyes for 5 min at $37^{\circ} \mathrm{C}$. After incubation, the cells were washed with HBSS two times. MEM containing $10 \%$ FBS was added to the wells and fluorescence images were taken with a confocal laser scanning microscope.

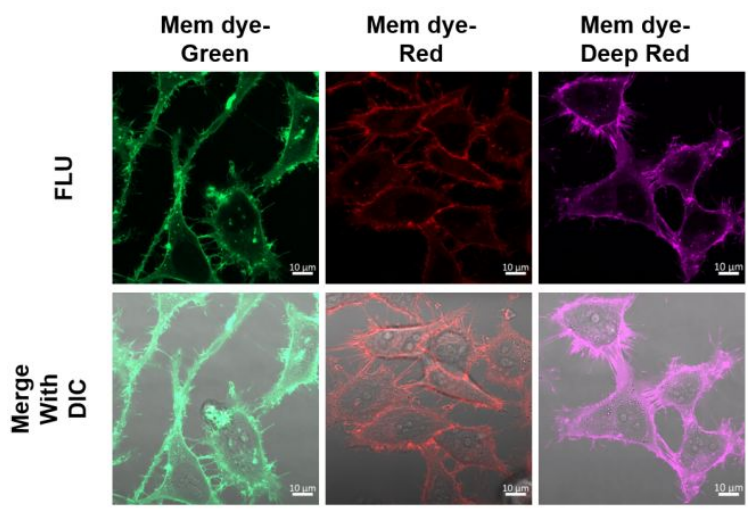

Figure S4. Fluorescence imaging of HeLa cells stained with Mem dyes.

The cells were incubated with Mem dyes for $5 \mathrm{~min}$ at $37^{\circ} \mathrm{C}$. Scale bars are $10 \mu \mathrm{m}$.

Fluorescent sEV staining

For PKH staining, HEK293S-derived sEVs were diluted in $50 \mu \mathrm{L}$ of PBS to a protein concentration of $20 \mu \mathrm{g} / \mathrm{mL}$, and then $20 \mu \mathrm{M}$ of PKH26 and PKH67 in $50 \mu \mathrm{L}$ of diluent $\mathrm{C}$ were added to the sEV solution and incubated at $37^{\circ} \mathrm{C}$ for $30 \mathrm{~min}$. For Mem dyes staining, HEK293Sderived sEVs were diluted in $100 \mu \mathrm{L}$ of PBS to a protein concentration of $10 \mu \mathrm{g} / \mathrm{mL}$. Then, 1 $\mu \mathrm{L}$ of $1 \mathrm{mM}$ Mem dyes/dimethylsulfoxide solution was added to the sEV solution and incubated at $37^{\circ} \mathrm{C}$ for $30 \mathrm{~min}$. All samples were prepared with a protein concentration of $10 \mu \mathrm{g} / \mathrm{mL}$ of sEVs and $10 \mu \mathrm{M}$ of each dye.

Purification of stained sEVs

The stained SEV samples were transferred to a 30k filtration tube (Pall, Mexico) and centrifuged at 3,000 $\times g$ for $5 \mathrm{~min}$ at room temperature. Stained sEVs were washed two times with $100 \mu \mathrm{L}$ of PBS before being concentrated to a final volume of $50 \mu \mathrm{L}$. 


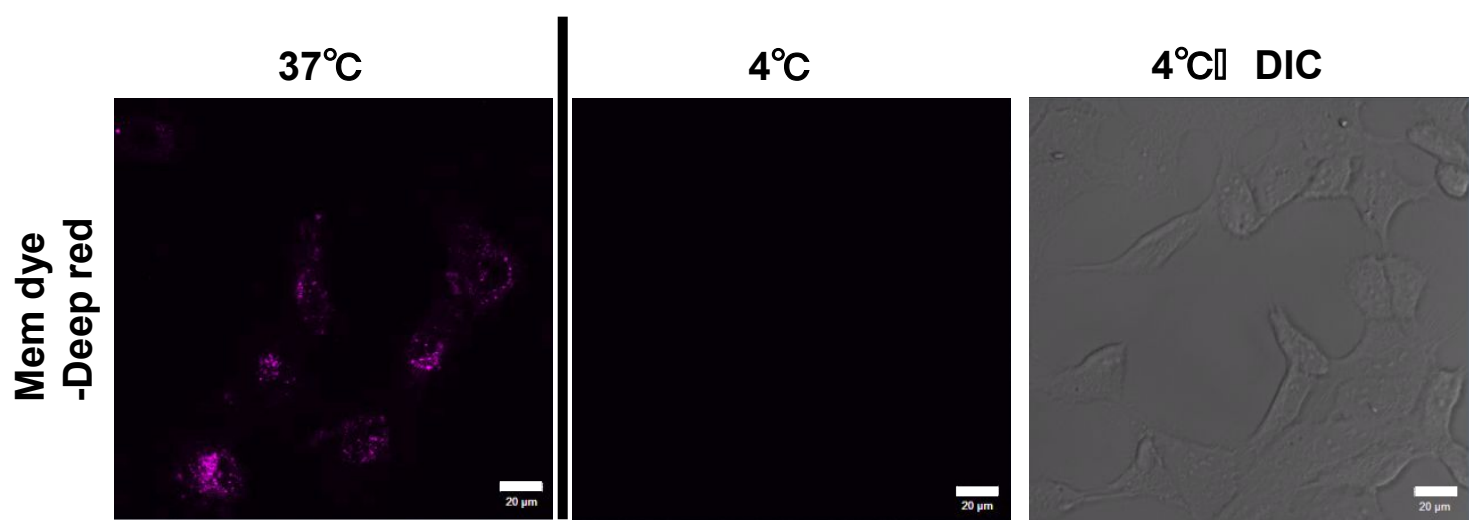

Figure S5. Monitoring of temperature-dependent sEV uptake in HeLa cells

Cultured cells were co-incubated with Mem dye-Deep Red labeled sEVs for $1 \mathrm{~h}$ at $37^{\circ} \mathrm{C}$ or 4 ${ }^{\circ} \mathrm{C}$. After washing twice with HBSS, MEM-containing 10\% FBS was added. Fluorescence images were taken with a confocal laser scanning microscope. Scale bars are $20 \mu \mathrm{m}$.

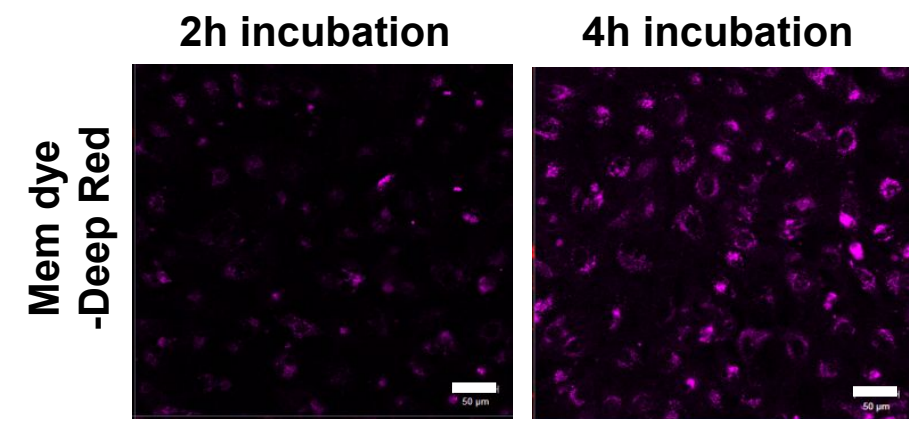

Figure S6. Monitoring of Mem dye-Deep Red-labeled sEV uptake in HeLa cells

Cultured cells were co-incubated with the labeled sEVs for 2 and $4 \mathrm{~h}$ at $37^{\circ} \mathrm{C}$. After washing twice with HBSS, MEM-containing 10\% FBS was added. Fluorescence images were taken with a confocal laser scanning microscope. Scale bars are $50 \mu \mathrm{m}$. 


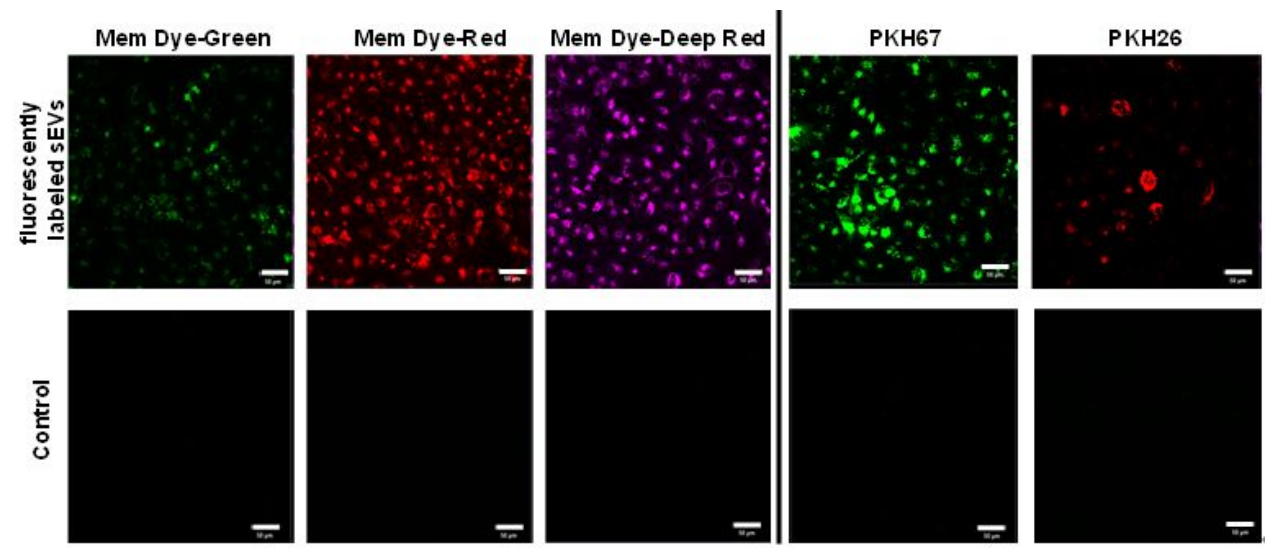

Figure S7. Monitoring of sEV uptake in HeLa cells

Cultured cells were co-incubated with either PKH-labeled or Mem dye-labeled sEVs for $24 \mathrm{~h}$ at $37^{\circ} \mathrm{C}$. The control was cells incubated without labeled sEVs, containing no dyes because of purification by ultrafiltration. After washing twice with HBSS, MEM containing $10 \%$ FBS was added. Fluorescence images were taken with a confocal laser scanning microscope.

Scale bars $=50 \mu \mathrm{m}$.

NTA and zeta potential measurement

The size distribution of sEVs was determined by NTA. The sEV solutions were analyzed using a NanoSight LM10 device with a blue laser. Experimental conditions were as follows: Measurement Time: 60 s; Blur: Auto; Detection Threshold: 4-5; Min Track Length: Auto; Min Expected Size: Auto. Data represent the mean \pm standard deviation (SD) of three independent experiments. Zeta potential measurements were carried out at $25{ }^{\circ} \mathrm{C}$ for each experimental triplicate. For NTA and zeta potential analysis, sEVs were diluted to a concentration of $1 \mu \mathrm{g}$ protein $/ \mathrm{mL}$.
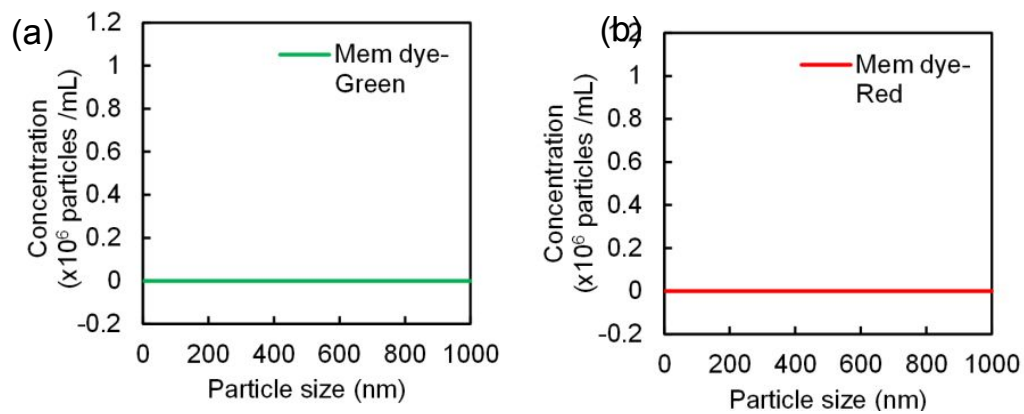

Figure S8. Nanoparticle tracking analysis of the amount and size distribution of dye aggregates. (a) Mem dye-Green or (b) Mem dye-Red. All the dyes were diluted at $10 \mu \mathrm{M}$ in $\mathrm{P}$ BS. Then, the samples were analyzed by NTA. 


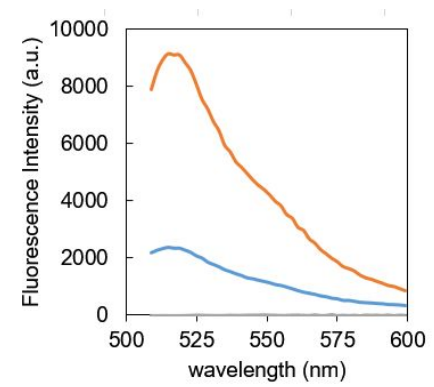

(a) Mem dye-Green

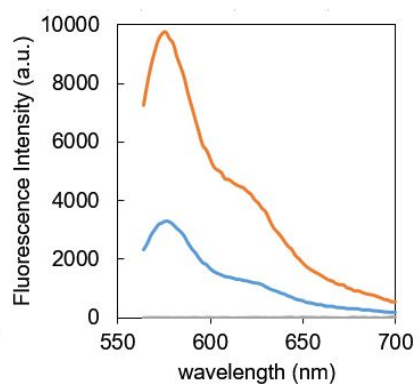

(b) Mem dye-Red

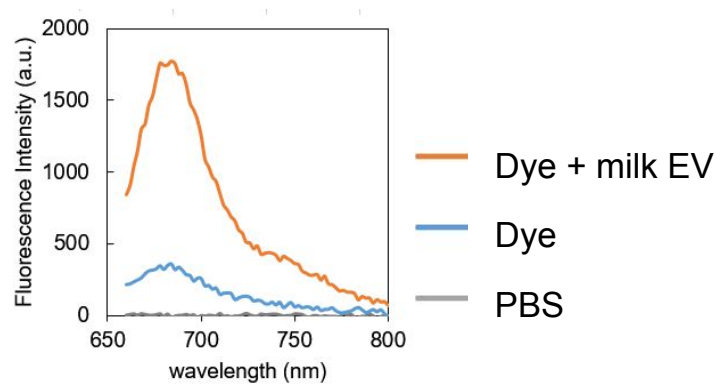

(c) Mem dye-Deep Red

Figure S9. Emission spectral changes of Mem dyes on labeling milk EVs. Milk EVs (EXBL100L, Cosmo Bio, Tokyo, Japan) were diluted in $100 \mu \mathrm{L}$ of PBS to a protein concentration of 10 $\mu \mathrm{g} / \mathrm{mL}$. Then, $1 \mu \mathrm{L}$ of $0.1 \mathrm{mM}$ Mem dye/dimethylsulfoxide solution was added to the milk EV solution and incubated at $37^{\circ} \mathrm{C}$ for $30 \mathrm{~min}$. All samples were measured using a fluorescence plate reader. (a) Mem dye-Green (excited at $470 \mathrm{~nm}$ ), (b) Mem dye-Red (excited at $530 \mathrm{~nm}$ ), and (c) Mem dye-Deep Red (excited at $630 \mathrm{~nm}$ ). 

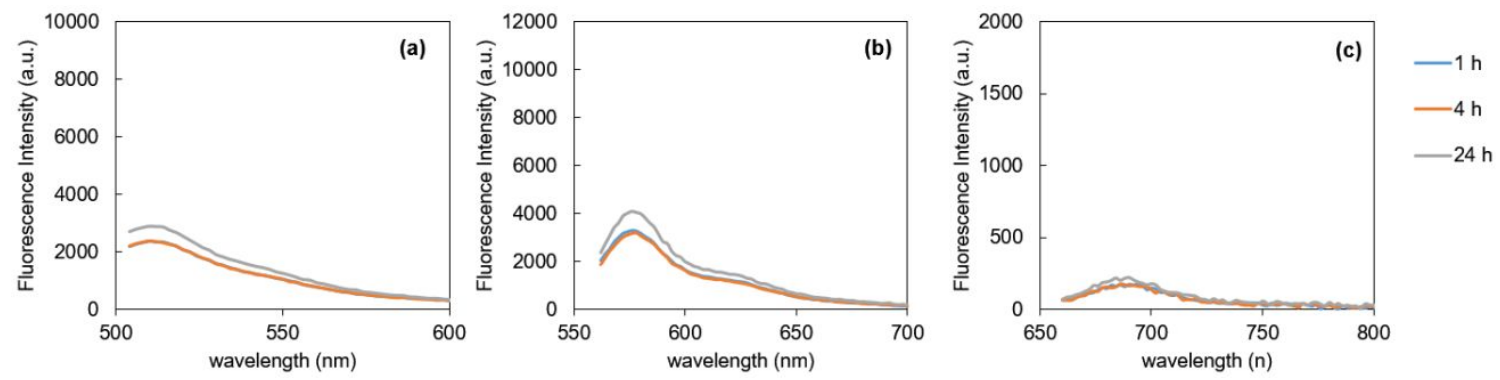

Figure S10. Time-dependent emission spectral changes of Mem dyes in PBS. Each Mem dye/PBS solution was prepared at $1 \mu \mathrm{M}$ dye and incubated at $37^{\circ} \mathrm{C}$ for 1,4 , or $24 \mathrm{~h}$. All samples were measured using a fluorescence plate reader. (a) Mem dye-Green (excited at $470 \mathrm{~nm}$ ), (b) Mem dye-Red (excited at $530 \mathrm{~nm}$ ), (c) Mem dye-Deep Red (excited at $630 \mathrm{~nm}$ ).
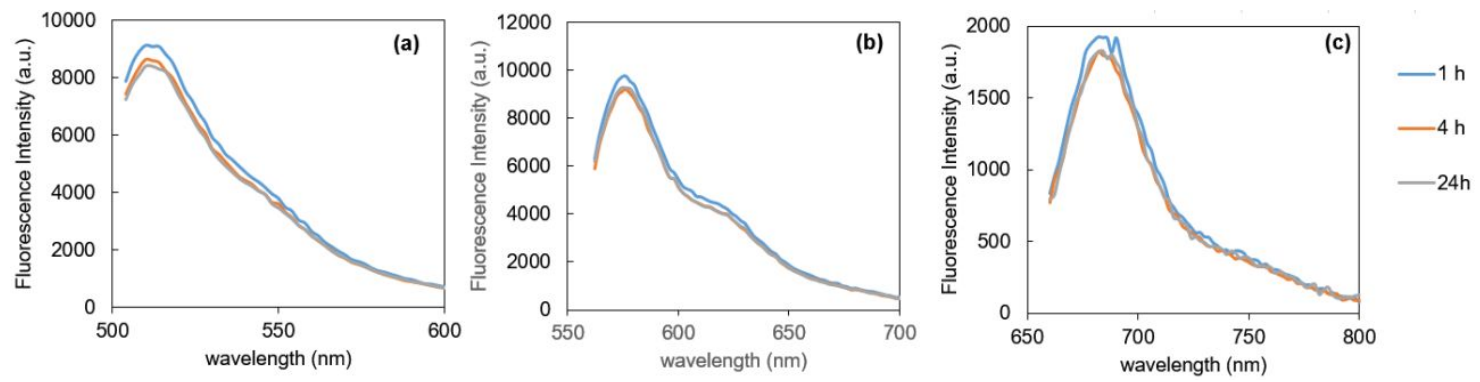

Figure S11. Time-dependent emission spectral changes of Mem dyes in PBS with milk EVs. Milk EVs (EXBL100L, Cosmo Bio, Tokyo, Japan) were diluted in $100 \mu \mathrm{L}$ of PBS to a protein concentration of $10 \mu \mathrm{g} / \mathrm{mL}$. Then, $1 \mu \mathrm{L}$ of $0.1 \mathrm{mM}$ Mem dye/dimethylsulfoxide solution was added to the milk EV solution and incubated at $37^{\circ} \mathrm{C}$ for 1,4 , or $24 \mathrm{~h}$. All samples were measured using a fluorescence plate reader. (a) Mem dye-Green (excited at $470 \mathrm{~nm}$ ), (b) Mem dye-Red (excited at $530 \mathrm{~nm}$ ), (c) Mem dye-Deep Red (excited at $630 \mathrm{~nm}$ ). 